\title{
Koyun orijinli Toxoplasma gondii izolatlarının multilokus PCR-RFLP yöntemi ile genotiplendirilmesi
}

\author{
Yılmaz Emre GENÇAY ${ }^{1 a}$, Sami GÖKPINAR ${ }^{2 b}$, Cahit BABÜR ${ }^{3 c}$, Kader YILDIZ $^{2 \mathrm{~d} \bowtie}$ \\ ${ }^{1}$ Copenhagen University, Faculty of Health and Medical Sciences, Department of Veterinary and Animal Sciences Section for Food \\ Safety and Zoonosis, Frederiksberg, Danimarka; ${ }^{2}$ Kırıkkale Üniversitesi, Veteriner Fakültesi, Parazitoloji Anabilim Dalı, Kırıkkale; \\ ${ }^{3}$ Türkiye Halk Sağlığı Kurumu, Parazitoloji Laboratuvarı, Ankara, Türkiye. \\ ${ }^{\mathrm{a}}$ ORCID: 0000-0002-2154-9663; ${ }^{\mathrm{b}}$ ORCID: 0000-0001-7071-869X; ${ }^{\mathrm{c} O R C I D: 0000-0002-1961-7305 \text {; }}$ \\ dORCID: 0000-0001-5802-6156
}

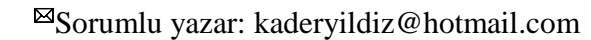

Geliş tarihi: 11.10.2018- Kabul tarihi: 04.05.2019

\begin{abstract}
Özet: Bu çalışmada doğal enfekte koyunlardan elde edilen Toxoplasma gondii izolatlarının (n:10) genotiplendirilmesi amaçlanmıştır. Bu amaçla T. gondii izolatlarının dokuz lokusu (SAG1, SAG2, c22-8, L358, 5'-SAG2, 3'-SAG2, SAG3, BTUB and PK1) multipleks multilokus nested PCR-RFLP yöntemi ile amplifiye edilmiştir. Bunun sonucunda koyun orijinli T. gondii izolatlarının bir dizi lokusta birden çok allel barındırdığı tespit edilmiştir. Koyun izolatları (n: 8) iki lokusta (alt.SAG2 ve SAG3) tip II ve III, bir lokusta (c22-8) klonal tip II, bir lokusta (5'-SAG2) tip I ve III, bir lokusta (L358) I ve II ve bir lokusta (3'-SAG2) ise tip I/III alleli göstermiştir. Bir koyun izolat1; iki lokusta (alt.SAG2 ve L358) tip I, bir lokusta (c22-8) tip II, bir lokusta (BTUB) tip I ve II, bir lokusta (3'-SAG2) ise I/III alleli göstermiştir. Sonuncu koyun izolatı ise üç lokusta (SAG1, alt.SAG2 ve SAG3) tip III, iki lokusta (c22-8 ve L358) tip II, bir lokusta (3'-SAG2) I/III, bir lokusta (BTUB) ise tip I ve II allelleri göstermiştir. Bu çalışma Türkiye'de koyunlarda $T$. gondii'nin genotiplendirilmesine ilişkin ilk rapordur. Genotiplendirmeye yönelik olarak parazite arakonaklık yapan farklı hayvanlardan ve çeşitli bölgelerden elde edilen izolatlar üzerinde çalışılması Türkiye'de $T$. gondii'nin bulaşma yolları ve tipleri hakkında önemli bilgiler elde etmeye katkı sağlayacaktır.

Anahtar sözcükler: Genotiplendirme, koyun, multilokus nested PCR RFLP, Toxoplasma gondii, Türkiye
\end{abstract}

\section{Genotyping of Toxoplasma gondii isolates originated from sheep by multilocus PCR-RFLP}

Abstract: The aim of the study was to determine the genotype of Toxoplasma gondii isolates obtained from sheep naturally infected. Genotyping was performed on the sheep isolates (n: 10) using multiplex multilocus nested PCR-RFLP at nine loci (SAG1, SAG2, c22-8, L358, 5'-SAG2, 3'-SAG2, SAG3, BTUB and PK1). Toxoplasma gondii isolates originated from sheep possessed multiple alleles at the same loci. The isolates (n:8) showed alleles of clonal type II and III at two loci (alt. SAG2 and SAG3), type II allele at the locus (c22-8), type I and III alleles at the locus 5'SAG2 and type I and II alleles at the locus L358, type I/III alleles at the locus 3'-SAG2. One isolate showed alleles of type I at four loci (alt. SAG2 and L358), type II allele at the locus c22-8 and type I and II alleles at the locus BTUB, type I/III alleles at the locus 3'-SAG2. One isolate showed alleles of type III at three loci (SAG1, alt. SAG2 and SAG3), type II allele at two loci (c22-8 and L358), type I/III alleles at the locus 3'-SAG2 and type I and II alleles at the locus BTUB. Genotyping may provide knowledge on infection route of $T$. gondii in people. To the author's knowledge, it is the first report on genotyping of $T$. gondii isolates originated from sheep in Turkey. Genotyping of isolates obtained from different hosts and from various regions will contribute to achieving the important knowledge about infection routes and clonal types of $T$. gondii in Turkey.

Keywords: Genotyping, multilocus nested PCR RFLP, sheep, Toxoplasma gondii, Turkey

\section{Giriş}

Dünya üzerinde en yaygın parazitik protozoonlardan biri olan Toxoplasma gondii'nin yaşam çemberinde kediler son konak, kedinin de dahil olduğu pek çok hayvan ve insan arakonaktır $(8,12)$. Toxoplasmatidae ailesi içinde yer alan tek tür olan $T$. gondii'nin dünya üzerinde farklı coğrafi bölgelerde subpopulasyonları vardır (30, 39).
Toxoplasma gondii izolatlarının tiplendirilmesinde Polimeraz Zincir Reaksiyonu Restriksiyon Parça Uzunluk Polimorfizmi (PCR RFLP), multilokus enzim elektroforezisi veya satellit analizi gibi yöntemler kullanılarak çok sayıda belirteç kullanılarak parazitin üç temel suş grubuna sahip olduğu belirlenmiştir (tip I, 2 ve 3 suşları) (19, 39). Tip I suşları (RH ve GT-1) nadiren 
izole edilmekte olup genelde insan orijinlidir (Avrupa ve ABD'den izole edilen $T$. gondii'ye ait suş koleksiyonunun \%10'unu tip I suşları oluşturur). Bu tipte yer alan suşlar in vitro ortamda hızla çoğalır ve tachyzoit-bradyzoit dönüşümü nispeten daha azdır $(24,39)$. Tip II suşları (ME49, PDS, PLK, PTg) arakonaklardan (koyun, insan ve domuz) en yaygın izole edilen suşlardır. Bu suşlar in vitro ortamda yavaş çoğalır, tachyzoit-bradyzoit dönüşümü ve kist oluşumu kolaydır (20, 24, 39). Tip III suşları (CEP ve VEG) ise rekombinant genotipler ve atipik alleller barındıran yaygın olmayan bir genotiptir. Yaban hayvanlarından orijin alan izolatlarda daha siktır $(24,39)$.

Konakta $T$. gondii ile enfeksiyonda gelişen tabloda parazit türü ve genotipi önemli role sahiptir. Farede, tip I suşları oldukça letal bir tablo şekillendirirken, aksine tip II ve III suşları nispeten daha az virulenttir $(24,33)$. İnsanda şekillenen toksoplasmosis esnasında asemptomatikten ciddi akut tabloya kadar değişen klinik görünüm izlenmektedir (39). İnsan toksoplasmosisinden genelde tip II suşlarının sorumlu olduğu belirtilmekle birlikte tip I veya tip I benzeri atipik $T$. gondii izolatları da insanda ciddi retinokoroiditis (16) ve akut toksoplasmosis sebebidir (7). Kuzey Amerika ve Avrupa'daki genotiplendirme çalışmalarında $T$. gondii'nin üç temel suş grubu (tip I, II ve III) tanımlanmıştır $(19,27)$. Benzer durum Afrika'dan da rapor edilmiştir (38). Ancak Güney Amerika'daki hayvan ve insan vakalarından elde edilen $T$. gondii izolatlarının Kuzey Amerika ve Avrupa'dakilerden oldukça farklı olduğu belirlenmiş ve bu farklı ve hiçbir tipe benzemeyen izolatlar "atipik ya da "ekzotik" izolatlar olarak tanımlanmıştır $(14,22,23)$.

Türkiye'de koyunlarda T. gondii enfeksiyonlarının yaygınlığına ilişkin çeşitli seroprevalans çalışmaları bulunmaktadır $(1,3,5,31,32,40)$. Ülkemizde hem çiftlik hayvanlarında hem de insanlarda toksoplasmozis seropozitifliği giderek arttığı izlenmektedir $(25,41)$. Buna ilişkin olarak yakın gelecekte muhtemel klinik toksoplasmosis olgularının önlenmesine yönelik yeni stratejilerin belirlenmesi gerekliliğinin ortaya çıkacağı şüphesizdir. Dünyanın pek çok bölgesinde $T$. gondii'nin enfekte ettiği konaklarda şekillenen hastalığın birbirinden farklı seyrettiği dikkat çekmiştir. Bu durumun sebepleri arasında öncelikle parazit suşları arasındaki virulens farklılığının olduğu ileri sürülmüştür. Türkiye'de $T$. gondii'nin genotiplendirilmesine ilişkin insan, kedi ve yabani kuşlardan bildirimler $(9,11,21)$ mevcut olmakla birlikte koyunlarda $T$. gondii'nin genotiplendirilmesine ilişkin henüz rapor bulunmamaktadır. Bu çalışmada doğal enfekte koyunlardan elde edilen $T$. gondii izolatlarının multipleks multilokus nested PCR RFLP yöntemi kullanılarak genotiplendirilmesi amaçlanmıştır.

\section{Materyal ve Metot}

Toxoplasma gondii izolatları: $\mathrm{Bu}$ çalışmada; Kırıkkale'de mezbahada rutin yapılan kesim sonrasında rastgele seçilen doğal enfekte koyunlara ait beyin dokularından elde edilen $10 \mathrm{~T}$. gondii izolatına ait genomik DNA ile Türkiye Halk Sağlığı Kurumu'nda toksoplasmosis teşhisi amacıyla rutin uygulanan Sabin Feldman boya testi için fare peritonunda pasajlanan $T$. gondii $\mathrm{RH}$ suşuna ait tachyzoitlerden elde edilen genomik DNA kullanılmıştır.

DNA ekstraksiyonu ve nested PCR: Doğal enfekte koyunlara ait beyin dokularından DNA ekstraksiyon kiti (DNeasy Blood \& Tissue Kits, Qiagen, Germany) firmanın belirtildiği biçimde uygulanarak genomik DNA'lar elde edilmiştir. Toxoplasma gondii B1 geninin varlığını doğrulamak için nested PCR yapılmıştır. İlk reaksiyonda B1 geninin 194 bp büyüklüğündeki kısmı Toxo 1 for: 5'-GGAACTGCATCCGTTCATGAG-3' ve Toxo 2 rev: 5'-TCTTTAAAGCGTTCGTGGTC-3' primerleri, ikinci reaksiyonda ilk reaksiyonda çoğaltılan DNA kısmı template olarak kullanılmış ve B1 geninin 97 bp'lik kısmı Toxo 3 for: 5'-TGCATAGGTTGCC AGTCACTG-3' ve Toxo 4 rev: 5'-GGCGACCAATCTG CGAATACACC-3' primerleri kullanılarak çoğaltılmıştır. Her iki PCR reaksiyonu $50 \mu$ l'lik hacimde olacak şekilde her bir primerden ( $30 \mathrm{pmol}) 1.5 \mu \mathrm{l}, 5 \mu \mathrm{l}$ 10XPCR buffer, $5 \mu \mathrm{l} 25 \mathrm{mM} \mathrm{MgCl} 2,4 \mu \mathrm{l} 1 \mathrm{mM}$ dNTP mix, $0.25 \mu \mathrm{l}$ of TaqDNA polymerase (1.25 IU; MBI Fermentas) ve template (ilk reaksiyonda $5 \mu \mathrm{l}$, ikinci reaksiyonda ise $2 \mu \mathrm{l}$ ) hazırlanmıştır. Reaksiyon karışımı $95^{\circ} \mathrm{C}$ 'de 5 dk'yı takiben 35 siklus boyunca $95^{\circ} \mathrm{C}^{\prime} \mathrm{de} 1 \mathrm{dk}, 55^{\circ} \mathrm{C}^{\prime} \mathrm{de} 1 \mathrm{dk}$ ve $72^{\circ} \mathrm{C}$ 'de $1 \mathrm{dk}$, takibinde $72^{\circ} \mathrm{C}$ 'de $5 \mathrm{dk}$ termal sicaklık değişimine tabi tutulmuştur (Esco Swift minipro, Güney Afrika). T. gondii RH suşuna ait DNA ile ultrasaf su pozitif ve negative DNA olarak kullanılmıştır. PCR ürünleri ethidium bromid ile boyalı agaroz jelde (\%1.5) yürütülmüş ve ultraviyole lamba ile izlenmiştir.

Genotiplendirme: Toxoplasma gondii'ye ait dokuz lokusun (SAG1, alt.SAG2, c22-8, L358, 5'-SAG2, 3'SAG2, SAG3, BTUB ve PK1) multipleks multilokus nested (m-Mn) PCR RFLP yöntemi kullanılarak amplifikasyonu sonucunda genotiplendirme gerçekleştirilmiştir $(35,36)$. Her bir lokus için hedef DNA, Fast start DNA polimeraz kullanılarak multipleks PCR (m-PCR) ile amplifiye edilmiştir. Reaksiyon: 1xPCR buffer, $2 \mathrm{mM}$ $\mathrm{MgCl}_{2}, 200 \mu \mathrm{M}$ dNTP, $0,15 \mu \mathrm{M}$ eksternal forward and reverse primerler, $1 \mathrm{U}$ FastStart DNA polymerase and 1,5 $\mu l$ DNA ekstraktı ile toplam 25 mikrolitre hacimde gerçekleştirilmiştir. Reaksiyon karışımı $95^{\circ} \mathrm{C}$ 'de $4 \mathrm{dk}$ 'yı takiben 30 siklus $94^{\circ} \mathrm{C}$ 'de $30 \mathrm{sn}, 55^{\circ} \mathrm{C}$ 'de $1 \mathrm{dk}$ ve $72^{\circ} \mathrm{C}$ 'de $2 \mathrm{dk}$ termal sicaklık değişiminine tabi tutulmuştur.

Laboratuvar çalışmaları esnasında m-PCR ile çoğaltılan lokuslar 1:1 sulandırıldıktan sonra nested-PCR 
aşaması için hedef DNA olarak kullanılmıştır. n-PCR 25 $\mu \mathrm{l}$ reaksiyon hacminde gerçekleştirilecek şekilde; 1xPCR buffer, $2 \mathrm{mM} \mathrm{MgCl}_{2}, 200 \mu \mathrm{M}$ her bir dNTP'den, 0,30 $\mu \mathrm{M}$ her bir internal ileri (forward) ve geri (reverse) primerlerden, $1 \mathrm{U}$ FastStart DNA polimeraz ve 1,5 $\mu \mathrm{l}$ sulandırılmış m-PCR ürünlerini içermiştir. Reaksiyon karışımına; $94^{\circ} \mathrm{C} 4 \mathrm{dk}$ ve 35 siklus; $94^{\circ} \mathrm{C} 30 \mathrm{sn}, 60^{\circ} \mathrm{C} 1 \mathrm{dk}$ ve $72^{\circ} \mathrm{C} 1,5 \mathrm{dk}$ sıcaklık uygulanmıştır.

Elde edilen n-PCR ürünlerinden alınan $5 \mu$ l'lik örnek, Tablo 1'de belirtildiği şekilde belirtilen restriksiyon enzimleriyle (NEB, ABD) kesilerek (Boeco Thermal Shaker, Germany) $0.3 \mathrm{mg} / \mathrm{ml}$ ethidium bromid içeren \%2.5-3'lük agaroz jelde yürütülmüş ve oluşan bant desenleri ultraviyole lamba altında incelenmiştir. Elde edilen sonuçlar referans suşlara (GT1, PTG, CTG, TgCgCa1, Mas, TgCatBr5, TgCatBr64 ve TgRSCr1) ait DNA'larda görülen band desenleri ile kıyaslanmıştır.

\section{Bulgular}

Çalışmada elde edilecek sonuçların güvenilirliği bakımından laboratuar çalışmaları Mn-PCR RFLP yönteminin standardize edilmesi ile başlamıştır. Bunun için öncelikle Tip I-III içinde yer alan referans suşlara (GT1, PTG, CTG, TgCgCa1, Mas, TgCatBr5, TgCatBr64 ve TgRSCr1) ait DNA'lar restriksiyon enzimleri ile kesilmek suretiyle deneyin standardizasyonu sağlanmış, reaksiyon sonucunda oluşan band desenleri ilgili literatür $(35,37)$ ile karşılaştırılarak doğrulanmıştır.

Türkiye Halk Sağlığı Kurumu'ndan temin edilen $T$. gondii RH suşuna ait tachyzoitlerden elde edilen genomic DNA, Mn-PCR RFLP kullanılarak genotiplendirilmiştir (Şekil 1). Mn-PCR RFLP metodunda restriksiyon enzimleri ile kesim sonrasında elde edilen ürünlerin agaroz jelde izlenen kesim profilinin, referans suşlar ile kıyaslanarak değerlendirilmesi sonucunda $T$. gondii $\mathrm{RH}$ suşunun 3'-SAG2 bölgesi dişında klonal Tip I alleli gösterdiği belirlenmiş, 3'-SAG2 bölgesinin ise tip I/III alleli gösterdiği izlenmiştir (Şekil 1).

Tablo 1. Koyun orijinli Toxoplasma gondii izolatlarının multipleks multilokus nested PCR-RFLP yöntemi kullanılarak genotiplendirilmesinde kullanılan lokuslar, primerler ve restriksiyon enzimleri (37).

Table 1. Loci, primers and restruction enzymes used genotyping of Toxoplasma gondii isolates originated from sheep by multiplex multilocus nested PCR-RFLP (37).

\begin{tabular}{|c|c|c|c|c|c|}
\hline Belirteç & $\begin{array}{l}\text { Multipleks PCR primerleri } \\
\text { (eksternal primerler) }\end{array}$ & $\begin{array}{l}\text { Nested PCR primerleri } \\
\text { (internal primerler) }\end{array}$ & $\begin{array}{l}\text { Büyüklük } \\
\text { (bp) }\end{array}$ & $\begin{array}{l}\text { Restriksiyon } \\
\text { enzimleri }\end{array}$ & $\begin{array}{l}\text { Enzim sindirimi } \\
\text { ve elektroforez }\end{array}$ \\
\hline $\mathrm{C} 22-8$ & $\begin{array}{l}\text { F: TGATGCATCCATGCGTTTAT } \\
\text { R: CCTCCACTTCTTCGGTCTCA }\end{array}$ & $\begin{array}{l}\text { F:TCTCTCTACGTGGACGCC } \\
\text { R:AGGTGCTTGGATATTCGC }\end{array}$ & 521 & $\begin{array}{l}\text { BsmA I, } \\
\text { Mbo II }\end{array}$ & $\begin{array}{l}\text { NEB2, BSA, } 37 \text { C } \\
30 \text { dak } 55 \text { C } 30 \\
\text { dak } \\
2.5 \% \text { jel }\end{array}$ \\
\hline L358 & $\begin{array}{l}\text { F: TCTCTCGACTTCGCCTCTTC } \\
\text { R: GCAATTTCCTCGAAGACAGG }\end{array}$ & $\begin{array}{l}\text { F: AGGAGGCGTAGCGCAAGT } \\
\text { R: CCCTCTGGCTGCAGTGCT }\end{array}$ & 418 & $\begin{array}{l}\text { Hae III, } \\
\text { Nla III }\end{array}$ & $\begin{array}{l}\text { NEB4, BSA, } 37 \mathrm{C} \\
60 \text { dak } 2.5 \% \text { jel }\end{array}$ \\
\hline SAG1 & $\begin{array}{l}\text { F: GTTCTAACCACGCACCCTGAG } \\
\text { R: AAGAGTGGGAGGCTCTGTGA }\end{array}$ & $\begin{array}{l}\text { F: CAATGTGCACCTGTAGGAAGC } \\
\text { R: GTGGTTCTCCGTCGGTGTGAG }\end{array}$ & 390 & $\begin{array}{l}\text { Sau961+ } \\
\text { HaeII (double } \\
\text { digest) }\end{array}$ & $\begin{array}{l}\text { NEB4, BSA, } 37 \text { C } \\
60 \text { dak } 2.5 \% \text { jel }\end{array}$ \\
\hline alt.SAG2 & $\begin{array}{l}\text { F: GGAACGCGAACAATGAGTTT } \\
\text { R: GCACTGTTGTCCAGGGTTTT }\end{array}$ & $\begin{array}{l}\text { F: ACCCATCTGCGAAGAAAACG } \\
\text { R: ATTTCGACCAGCGGGAGCAC }\end{array}$ & 546 & $\begin{array}{l}\text { Hinfl+Taql, } \\
\text { NEB3 }\end{array}$ & $\begin{array}{l}\text { BSA, } 37 \mathrm{C} \\
60 \text { dak } 2.5 \% \text { jel }\end{array}$ \\
\hline 5'-SAG2 & $\begin{array}{l}\text { Gerekli değil. SAG2 external primerleri } \\
5 \text { '-SAG2 için gerekli DNA fragmentini } \\
\text { içerir. }\end{array}$ & $\begin{array}{l}\text { F: GAAATGTTTCAGGTTGCTGC } \\
\text { R: GCAAGAGCGAACTTGAACAC }\end{array}$ & 242 & Mbol, NEB4, & $\begin{array}{l}\text { BSA, } 37 \text { C } 1 \text { saat, } \\
2.5 \% \text { jel }\end{array}$ \\
\hline 3'-SAG2 & $\begin{array}{l}\text { F: TCTGTTCTCCGAAGTGACTCC } \\
\text { R: TCAAAGCGTGCATTATCGC }\end{array}$ & $\begin{array}{l}\text { F: ATTCTCATGCCTCCGCTTC } \\
\text { R: AACGTTTCACGAAGGCACAC }\end{array}$ & 222 & Hhal, NEB4 & $\begin{array}{l}\text { BSA, } 37 \text { C } 1 \text { saat, } \\
2.5 \% \text { jel }\end{array}$ \\
\hline SAG3 & $\begin{array}{l}\text { F: CAACTCTCACCATTCCACCC } \\
\text { R: GCGCGTTGTTAGACAAGACA }\end{array}$ & $\begin{array}{l}\text { F: TCTTGTCGGGTGTTCACTCA } \\
\text { R: CACAAGGAGACCGAGAAGGA }\end{array}$ & 225 & $\begin{array}{l}\text { NciI, NEB4 } \\
\text { NciI+Taq1 } \\
\text { (double } \\
\text { digest), NEB4 }\end{array}$ & $\begin{array}{l}\text { BSA, } 37 \mathrm{C} \\
60 \text { dak } 2.5 \% \text { jel }\end{array}$ \\
\hline BTUB & $\begin{array}{l}\text { F: TCCAAAATGAGAGAAATCGT } \\
\text { R: AAATTGAAATGACGGAAGAA }\end{array}$ & $\begin{array}{l}\text { F: GAGGTCATCTCGGACGAACA } \\
\text { R: TTGTAGGAACACCCGGACGC }\end{array}$ & 411 & $\begin{array}{l}\text { BsiEI+TaqI } \\
\text { (double } \\
\text { digest), NEB4 }\end{array}$ & $\begin{array}{l}\text { BSA, } 37 \mathrm{C} \\
60 \text { dak } 2.5 \% \text { jel }\end{array}$ \\
\hline Apico & $\begin{array}{l}\text { F:TGGTTTTAACCCTAGATTG TGG } \\
\text { R: AAACGGAATTAATGAGATTT } \\
\text { GAA }\end{array}$ & $\begin{array}{l}\text { F: GCAAATTCTTGAATTCTCAGTT } \\
\text { R: GGGATTCGAACCCTTGATA }\end{array}$ & 640 & $\begin{array}{l}\text { Afl II+DdeI } \\
\text { (double } \\
\text { digest), NEB2 }\end{array}$ & $\begin{array}{l}\text { BSA, } 37 \text { C } 1 \text { saat, } \\
2.5 \% \text { jel }\end{array}$ \\
\hline
\end{tabular}



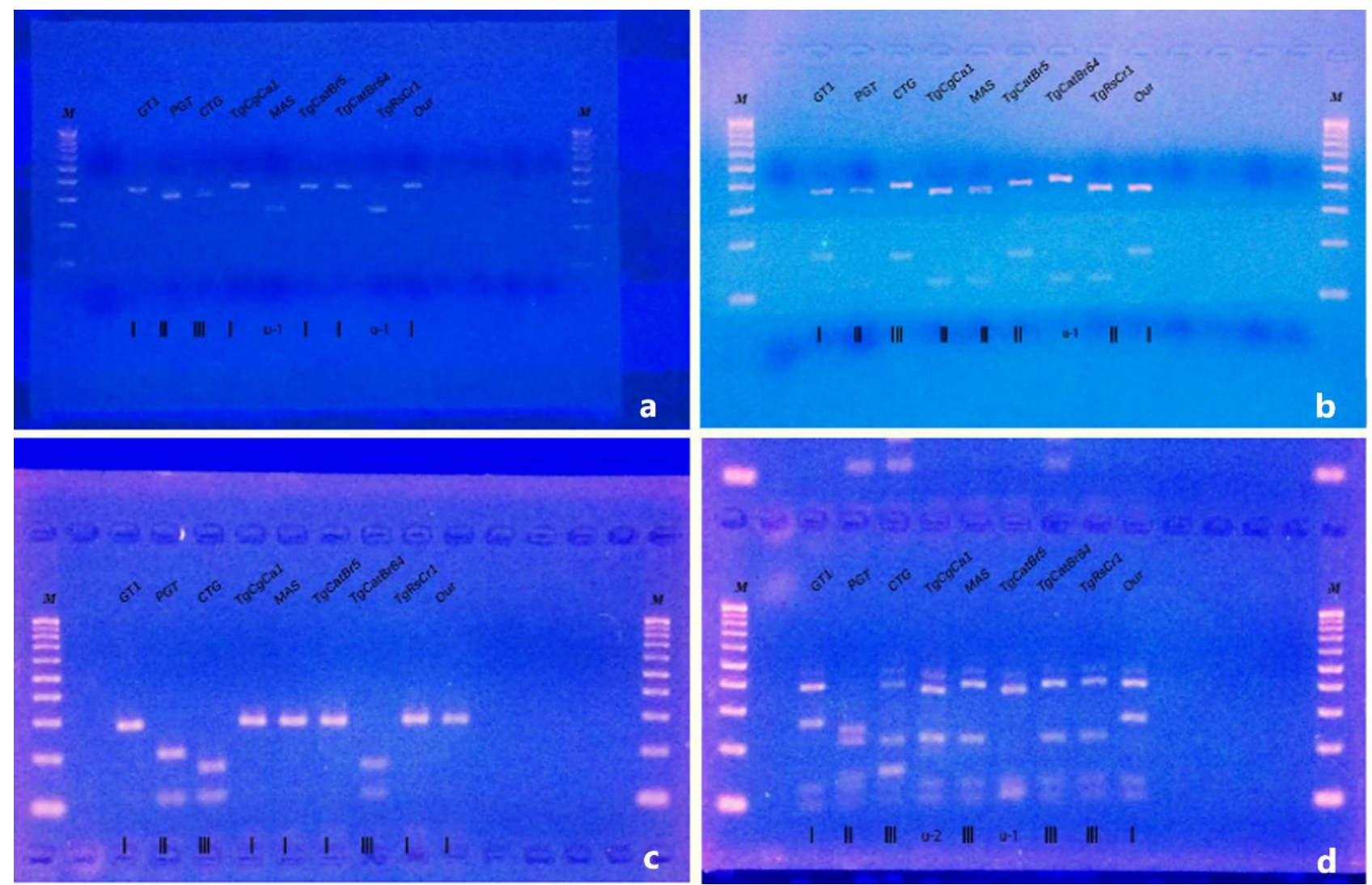

Şekil 1. Toxoplasma gondii RH suşuna ait dört lokusun (1.a: SAG1, 1.b:alt. SAG2, 1.c: L358, 1.d: PK1) kullanılarak yapılan multipleks multilokus nested PCR-RFLP sonuçları. GT1, PTG, CTG, TgCgCal, MAS, TgCatBr5, TgCatBr64 ve TGRsCr1, T. gondii tip I-III'e ait referans suşlardır. Our: RH suşu (Şekil 1.a, 1.b, 1.c ve 1.d'de en sağda yer almaktadır) tip I içinde yer alan suşlara ait band deseni göstermiştir. M: DNA ladder.

Figure 1. The multiplex multilocus nested PCR-RFLP results of four loci of Toxoplasma gondii RH isolate (1.a: SAG1, 1.b: alt.SAG2, 1.c: L358, 1.d: PK1). GT1, PTG, CTG, TgCgCal, MAS, TgCatBr5, TgCatBr64 and TGRsCr1 are reference strains of T. gondii clonal type I-III. Our: RH strain had uniform typing band patterns of type 1 strain (in the right column on Figure 1.a, 1.b, 1.c and 1.d). M: Low molecular weight DNA ladder.

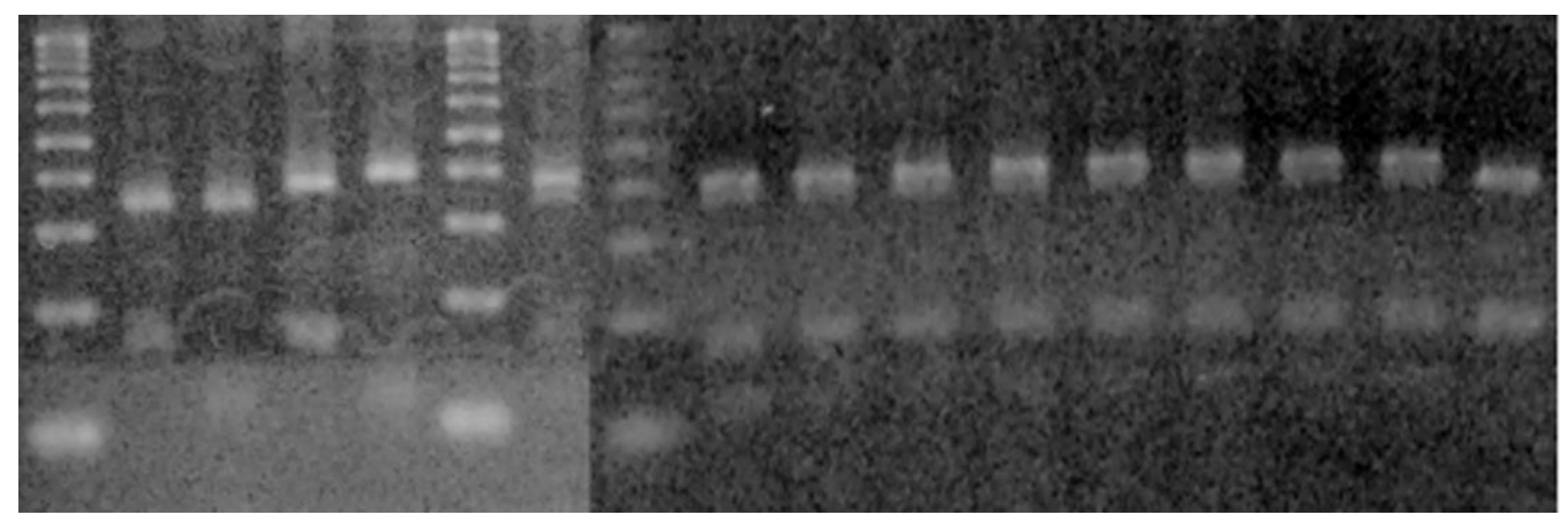

Şekil 2. Toxoplasma gondii koyun izolatlarının alt.SAG2 lokusunun multipleks multilokus nested PCR-RFLP sonucu. Soldan sağa sırayla: DNA ladder, CT1, PTG, CTG ve TgcatBr64 referans suşları, DNA ladder, $T$. gondii RH suşu, DNA ladder, 1-8 nolu koyun izolatlar1.

Figure 2. The multiplex multilocus nested PCR-RFLP results of alt.SAG2 locus of Toxoplasma gondii sheep isolates. From right to left, low molecular weight DNA ladder, CT1, PTG, CTG and TgcatBr64 reference strains, DNA ladder, T. gondii RH strain, DNA ladder, the sheep isolates (no: 1-8). 
Şekil 3. Toxoplasma gondii koyun izolatlarının SAG3 lokusunun multipleks multilokus nested PCRRFLP sonucu. Soldan sağa sirayla: DNA ladder, CT1, PTG ve CTG referans suşları, 1-8 nolu koyun izolatları ve DNA ladder.

Figure 3. The multiplex multilocus nested PCR-RFLP results of SAG3 locus of Toxoplasma gondii sheep isolates. From right to left, low molecular weight DNA ladder, CT1, PTG and CTG reference strains, the sheep isolates (no: 1-8) and DNA ladder.

Şekil 4. Toxoplasma gondii koyun izolatlarının 5'-SAG2 lokusunun multipleks multilokus nested PCRRFLP sonucu. Soldan sağa sirayla, DNA ladder, CTG referans suşu, $T$. gondii RH suşu, DNA ladder, 1-7 nolu koyun izolatları ve DNA ladder.

Figure 4. The multiplex multilocus nested PCR-RFLP results of 5'SAG2 locus of Toxoplasma gondii sheep isolates. From right to left, low molecular weight DNA ladder, CTG reference strain, $T$. gondii $\mathrm{RH}$ strain, DNA ladder, the sheep isolates (no: 1-7) and DNA ladder.
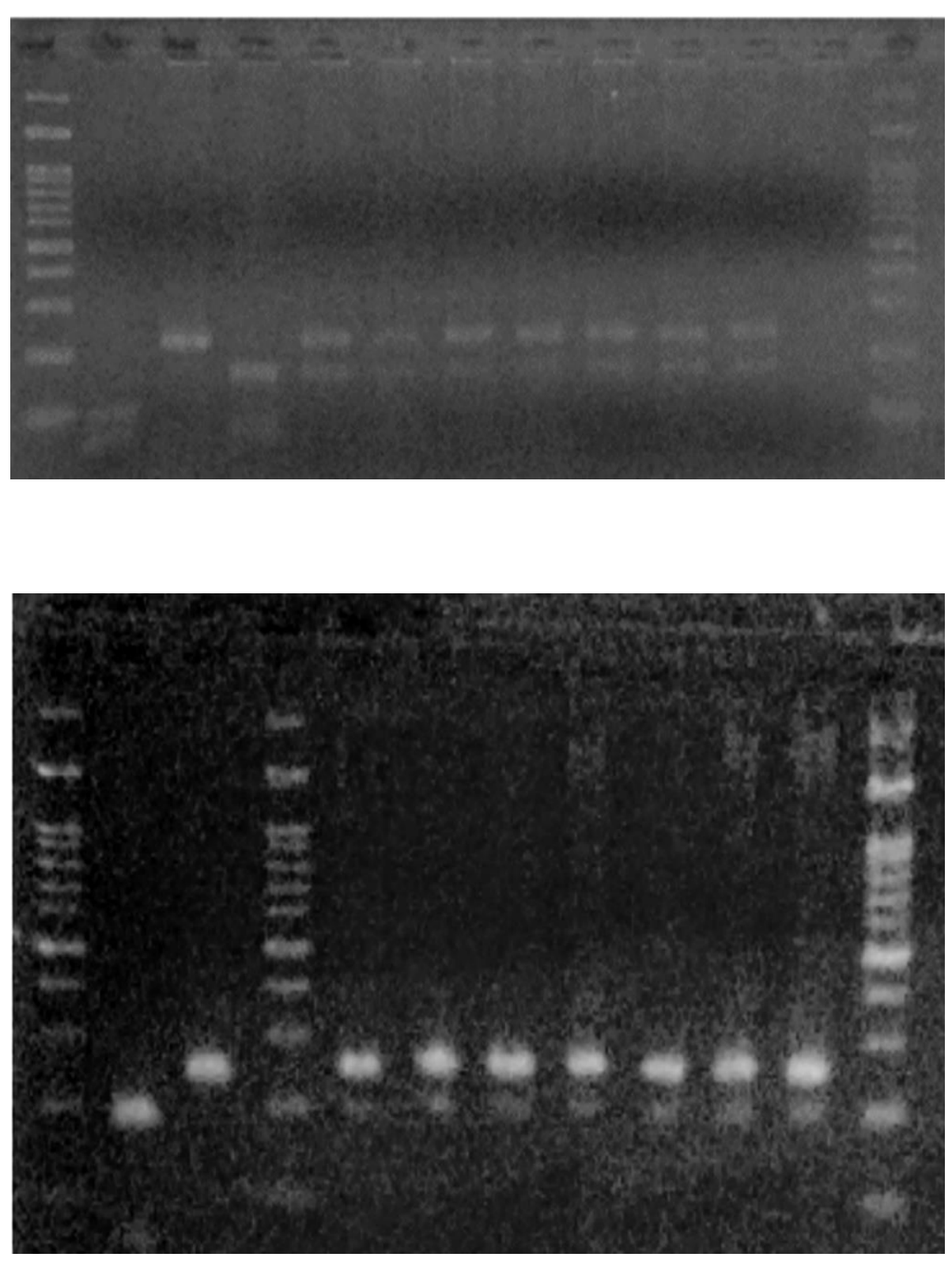

Şekil 5. Toxoplasma gondii koyun izolatlarının L358 lokusunun multipleks multilokus nested PCRRFLP sonucu. Soldan sağa sırayla, DNA ladder, CT1, PTG ve CTG referans suşları, $T$. gondii RH suşu, DNA ladder, koyuna ait 1-8 nolu örnekler ve DNA ladder.

Figure 5. The multiplex multilocus nested PCR-RFLP results of L358 locus of Toxoplasma gondii sheep isolates. From right to left, low molecular weight DNA ladder, CT1, PTG and CTG reference strains, $T$. gondii RH strain, DNA ladder, sheep isolates (no: 1-8) and DNA ladder.

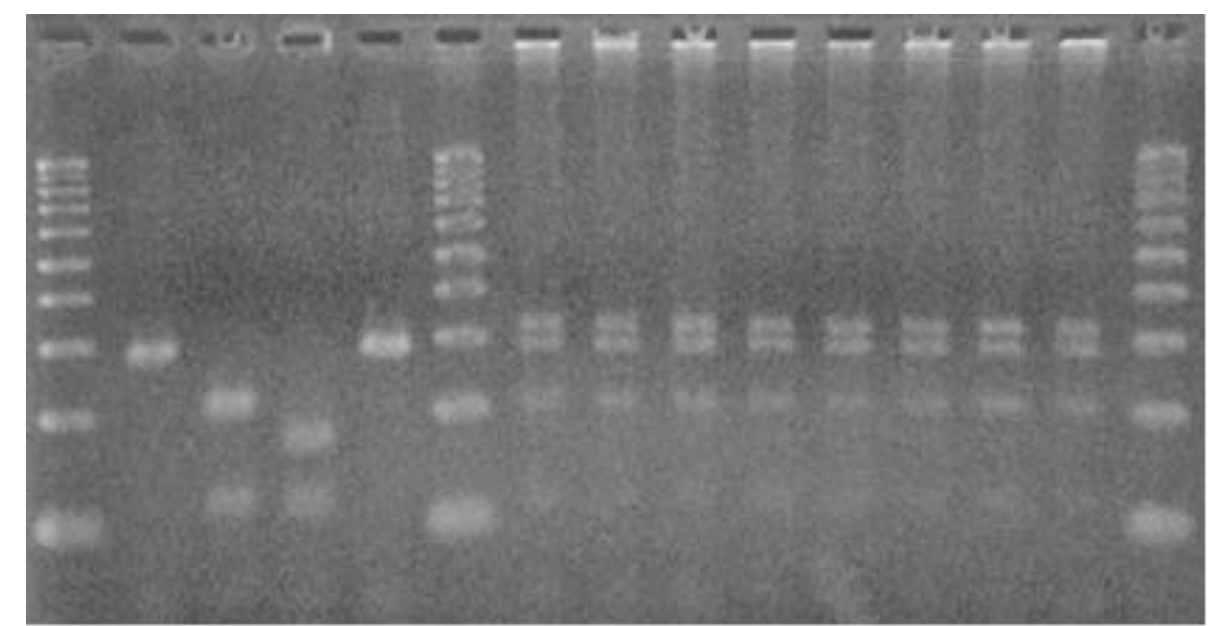


Tablo 2. Koyun dokularından elde edilen Toxoplasma gondii genomik DNA'ları (n: 10) ile T. gondii RH suşunun multipleks multilokus nested PCR-RFLP sonuçları.

Table 2.The multiplex multilocus nested PCR-RFLP results obtained from genomic DNA of Toxoplasma gondii originated from sheep (n:10) and T. gondii RH strain.

\begin{tabular}{|c|c|c|c|c|c|c|c|c|}
\hline \multirow{2}{*}{$\begin{array}{c}\text { İzolat } \\
\text { no. }\end{array}$} & \multicolumn{8}{|c|}{ Genotiplendirmede kullanılan lokuslar } \\
\hline & SAG1 & 5'-SAG2 & 3'SAG2 & alt.SAG2 & SAG3 & BTUB & c22-8 & L358 \\
\hline RH suşu & I & $\mathrm{I}$ & I/III & I & I & I & I & I \\
\hline 1 & PCR - & I+III & I/III & II+III & II+III & PCR - & II & $\mathrm{I}+\mathrm{II}$ \\
\hline 2 & PCR - & I+III & I/III & II+III & II+III & PCR - & II & $\mathrm{I}+\mathrm{II}$ \\
\hline 3 & PCR - & I+III & I/III & II+III & II+III & PCR - & II & $\mathrm{I}+\mathrm{II}$ \\
\hline 4 & PCR - & I+III & I/III & II+III & II+III & PCR - & II & $\mathrm{I}+\mathrm{II}$ \\
\hline 5 & PCR - & I+III & I/III & II+III & II+III & PCR - & II & $\mathrm{I}+\mathrm{II}$ \\
\hline 6 & PCR - & I+III & I/III & II+III & II+III & PCR - & II & $\mathrm{I}+\mathrm{II}$ \\
\hline 7 & PCR - & I+III & I/III & II+III & II+III & PCR - & II & $\mathrm{I}+\mathrm{II}$ \\
\hline 8 & PCR - & I+III & I/III & II+III & PCR - & PCR - & II & I+II \\
\hline 9 & PCR - & III değil & I/III & I & PCR - & $\mathrm{I}+\mathrm{II}$ & II & I \\
\hline 10 & III & III değil & I/III & III & III & $\mathrm{I}+\mathrm{II}$ & II & II \\
\hline
\end{tabular}

Koyundan elde edilen genomik DNA'ların (n:10) Mn-PCR RFLP sonuçları Tablo 2'de görülmektedir. Koyun orijinli $T$. gondii izolatlarının birden fazla klonal tip özelliği gösterdiği belirlenmiştir. Toxoplasma gondii izolatlar1 (n:8) iki lokusta (alt.SAG2 ve SAG3) tip II ve III (Şekil 2 ve 3), bir lokusta (c22-8) klonal tip II, bir lokusta (5'-SAG2) tip I ve III (Şekil 4), bir lokusta (L358) tip I ve II, bir lokusta (3'-SAG2) ise tip I/III alleli göstermiştir (Şekil 5). Bu izolatlarda SAG1 ve BTUB lokusları PCR ile amplifiye edilememiştir (Tablo 2).

Bir T. gondii izolat1 iki lokusta (alt.SAG2 ve L358) tip I, bir lokusta (c22-8) tip II, bir lokusta (BTUB) tip I ve II, bir lokusta (3'-SAG2) ise I/III alleli göstermiş, SAG1 ve SAG3 lokusları PCR ile amplifiye edilememiştir (Tablo 2).

Bir T. gondii izolatı ise üç lokusta (SAG1, alt.SAG2 ve SAG3) tip III, 2 lokusta (c22-8 ve L358) tip II, bir lokusta (3'-SAG2) tip I/III, bir lokusta (BTUB) ise tip I ve II allelleri göstermiş, 5'-SAG2 lokusu PCR ile amplifiye edilememiştir (Tablo 2). PK1 lokusu koyun orijinli genomik DNA örneklerinin hiçbirinden (n:10) amplifiye edilememiştir.

\section{Tartışma ve Sonuç}

Dünya üzerinde farklı ülkelerde $T$. gondii izolatları multilokus enzim elektroforezi, PCR RFLP veya satellit analizi gibi yöntemler kullanılarak genotiplendirilmektedir $(2,14,22-24,29,38)$. PCR RFLP kullanılarak genotiplendirme yapılabilmesi için DNA ekstraksiyonu yapılacak örneğin yeterli miktarda parazit DNA'sını içermesi gerektiği ifade edilmiştir (6). Toxoplasma gondii ile ilgili olarak PCR RFLP yöntemi kullanılarak yapılan genotiplendirme çalışmalarında doğal enfekte konak dokularından elde edilen DNA'ların tümünün sonuç vermediği bildirilmiştir (6). PCR RFLP yöntemi ile sığır ve domuz orijinli genomik DNA'da T. gondii izolatlarının sadece bir ya da iki lokusu amplifiye edilebilmiş, aynı lokusta birden çok allel barındıran izolatların gözlenmesi ise araştırıcılar tarafından konağın farklı genotiplerdeki $T$. gondii ile enfekte olduğu şeklinde yorumlanmıştır (6). Ayrıca PCR RFLP sonucunda bir dizi lokusta farklı allellerin gözlendiği örnekler ise atipik $T$. gondii ile enfeksiyonun göstergesi olarak ileri sürülmüştür (6). Bu çalışmada, PCR RFLP yöntemi ile $T$. gondii'ye ait dokuz lokusun hepsi tüm koyun izolatlarında amplifiye edilememiştir. $\mathrm{Bu}$ durumun sebebinin doğal enfekte koyunlardan elde edilen genomik DNA içinde $T$. gondii'ye ait DNA miktarının az olması olabileceği düşünülmüştür. Ayrıca koyun kaynaklı T. gondii suşlarının bir dizi lokusta birden çok allel barındırdığı tespit edilmiştir. Bu koyunların genotipik olarak farklı $T$. gondii suşları ile enfekte olduğu düşünülmüştür.

İsviçre'de koyun diyafram örneklerinden elde edilen genomik DNA, PCR-RFLP ile genotiplendirildiğinde koyunlarda klonal tip II alellerinin baskın olduğu anlaşılmıştır, buna karşılık örneklenen koyunlarda miks ya da atipik alel kombinasyonları nadir görülmüştür (6). İsviçre'de sığırların tip I ya da II, atipik $T$. gondii ya da birden fazla tip ile enfekte olduğu bildirilmiş̧ir (6). Benzer raporlar İngiltere (26), Fransa $(15,17)$ ve Danimarka (20) gibi diğer ülkelerden de kaydedilmiştir. İran'da koyun, sığır ve tavuk etlerinden elde edilen $T$. gondii izolatlarının SAG2 lokusu kullanılarak yapılan genotiplendirmesi sonucunda tip I özelliğinde olduğu bildirilmiştir (24). Hindistan'da SAG3 lokusu kullanılarak genotiplendirilen koyun ve keçi izolatlarının ise tip II ve tip III'e ait olduğu belirlenmiştir $(24,29)$. T. gondii'nin genotiplendirilmesinde sadece bir genetik lokus kullanılması $(24,29)$ elde edilen sonuçların güvenilirliği tartışmalıdır. Bu çalışmada ise koyun orijinli $T$. gondii izolatlarına ait dokuz lokus Mn-PCR RFLP ile amplifiye edilmiş ve koyunların birden fazla tip (I, II ve III) T. gondii ile enfekte olduğu tespit edilmiştir. 
Türkiye'de T. gondii'nin genotiplendirilmesine ilişkin sınırlı sayıda bilgi görülmektedir (9, 11, 21). Yenidoğan kongenital toksoplasmosisli bebeklerden izole edilen Ankara ve Ege-1 olarak adlandırılan iki izolatının mikrosatellit analizi sonucunda Afrika 1 genotipinde yer aldığını belirlenmiştir (11). İzmir'de 22 sokak kedisi izolatının mikrosatellit analizi sonucunda 19'unun tip I, ikisinin tip II ve birinin ise Afrika 1 genotipinde olduğu bildirilmiştir (9). İzmir'de yabani kuşlardan elde edilen 14 izolat mikrosatellit markerı kullanılarak genotiplendirilmiş ve sekiz izolatın tip II, üçünün tip III, ikisinin tip II/II ve birinin ise tip II/III olduğu görülmüştür (21). Bu çalışmada ise koyunlardan elde edilen izolatların dokuz lokusunun Mn PCR RFLP yöntemi ile analizi sonrasında birden fazla tipte (I, II ve III) $T$. gondii genotipine sahip olduğu tespit edilmiştir.

Doğada T. gondii'nin farklı tiplerinde seksüel rekombinasyon nadiren görülmektedir. Yaşam çemberinde son konağın bağırsağında $T$. gondii'nin tek bir tipin kendi içinde eşeyli çoğalması sonucunda (self-mating) ürediği farz edilmektedir. Bu iddia hayvan ve insanlardan elde edilen $T$. gondii izolatlarının büyük oranda üç klonal yapıya ait olması ile açıklanmaktadır (4, 10). Ancak moleküler genotiplendirme yöntemleri kullanılarak yapılan çalışmalar arttıkça özellikle de Güney Amerika ve Asya'da bu klonal tiplerden farklı özellik gösteren, "atipik" ya da "ekzotik" olarak adlandırılan $T$. gondii izolatları rapor edilmektedir $(13,23,30,37)$. Atipik genotiplerin, sonkonak kedinin birden fazla tiple enfekte olmuş arakonağ1 yemesi sonucu ortaya çıktığı düşünülmektedir. Böyle bir durumda, farklı tipteki $T$. gondii kedi bağırsağında seksüel olarak rekombine olabilmekte ve sonucunda iki ebeveyn genotipinin karışımını gösterecek yeni bir nesil oluşmaktadır $(23,28,30,35)$. Bu durum hem birden fazla genotiple deneysel enfekte kedilerde $(4,10)$ hem de doğal enfekte kedilerde izlenmiştir (18). Doğal enfekte kedilerden elde edilen $T$. gondii oocystlerinin PCR RFLP ile genotiplendirilmesi sonucunda pek çok lokusta tip I ve tip II spesifik allellerin karışımını içeren band deseni gözlendiği bildirilmiştir (16). Doğada farklı parazit genotipleri arasında eşeyli çoğalma sonucunda daha fazla T. gondii suşu oluşma potansiyeli vardır ve bu durum gerek insan gerekse hayvanlar için virulensi artan, yeni biyolojik özelliklere sahip parazit suşlarını ortaya çıkarabilir (16). Ayrıca T. gondii'nin pek çok canlıyı arakonak olarak kullanabilmesi, ayrica hem silvatik hem de evcil yaşam çemberine sahip olması nedeniyle farklı tipte yeni parazit suşları şekillenebilir (16). Bu çalışmada da koyundan izole edilen $T$. gondii izolatları pekçok lokusta tip I, II ve III spesifik alellerinin karışımını içeren band deseni göstermiştir. Çiftlik hayvanları ile iç içe yaşayan kedi hem arakonak canlılara paraziti bulaştırabilmekte hem de arakonak canlıların enfekte dokularına kolaylıkla ulaşabilmektedir. Dünyanın farklı coğrafi bölgelerinde yaşayan ve parazite arakonaklık yapan çiftlik hayvanları aracılığıyla farklı genotipteki $T$. gondii'nin Türkiye'ye girebilme ihtimali vardır. Arakonak canlıların dokularındaki farklı genotipteki parazitlerin yenilmesi sonucunda kedilerde yeni atipik suşların gelişmiş olmasından dolayı bu çalışmada koyun dokularından izole edilen $T$. gondii izolatlarının birden fazla tip özelliği gösterdiği düşünülmüştür.

Sonuç olarak, T. gondii önemli bir gıda kaynaklı parazittir (12). Türkiye'de insanlar için gıda kaynaklı toksoplasmosisin önemli kaynaklarından birisinin koyunlar olduğu düşünülmektedir. Genotiplendirme ile insanların toksoplasmosisle hangi yolla enfekte olabildiğine dair bilgi sağlanabilir. Buna ilişkin yapılan bir çalışmada aynı bölgede yaşayan insan ve hayvanlarda benzer T. gondii genotipleri bulunduğu bildirilmiştir (34). $\mathrm{Bu}$ çalışma Türkiye'de koyun orijinli T. gondii izolatlarında ilk genotiplendirme çalışmasıdır. Genotiplendirmeye yönelik olarak parazite arakonaklık yapan farklı hayvanlardan ve çeşitli bölgelerden elde edilen izolatlar üzerinde çalışılması Türkiye'de $T$. gondii'nin bulaşma yolları ve populasyon yapısı hakkında önemli bilgiler elde etmeye katkı sağlayacaktır.

\section{Teşekkür}

Genotiplendirmede kullanılan referans DNA'lar Tennessee Üniversitesi Mikrobiyoloji Departmanı'nda çalışan Dr. Chunlei SU'dan temin edilmiştir. Bu çalışma Kırıkkale Üniversitesi Bilimsel Araştırmalar Koordinasyon Birimi tarafından desteklenmiştir (Proje numaras1: 2013-73).

\section{Kaynaklar}

1. Açıcı M, Babür C, Kılıç S ve ark. (2008): Prevalence of antibodies to Toxoplasma gondii infection in humans and domestic animals in Samsun province, Turkey. Trop Anim Health Prod, 40, 311-315.

2. Ajzenberg D, Banuls AL, Tybayrenc M ve ark. (2002): Microsatellite analysis of Toxoplasma gondii shows considerable polymorphism structured into two main clonal groups. Int J Parasitol, 32, 27-38.

3. Aktaş M, Dumanlı N, Babür C ve ark. (2000): Determination of seropositivity for Toxoplasma gondii infection in pregnant and aborted sheep in Elazıg and vicinity by Sabin-Feldman (SF) test. Turk J Vet Anim Sci, 24, 239-241.

4. Araujo F, Slifer T, Kim S (1997): Chronic infection with Toxoplasma gondii does not prevent acute disease or colonization of the brain with tissue cysts following reinfection with different strains of the parasite. J Parasitol, 83, 521-522.

5. Babür C, Karaer Z (1997): Isolation and seroincidence studies of Toxoplasma gondii infection in sheep. Turkiye Parazitol Derg, 21, 293-299.

6. Berger-Schoch AE, Herrmann DC, Schares G ve ark. (2011): Prevalence and genotypes of Toxoplasma gondii in 
feline faeces (oocysts) and meat from sheep, cattle and pigs in Switzerland. Vet Parasitol, 177, 290-297.

7. Bossi P, Bricaire F (2004): Severe acute disseminated toxoplasmosis. The Lancet, 364, 579.

8. Buxton D, Maley SW, Wright SE ve ark. (2007): Toxoplasma gondii and ovine toxoplasmosis: New aspects of an old story. Vet Parasitol, 149, 25-28.

9. Can H, Doskaya M, Ajzenberg D ve ark. (2014): Genetic characterization of Toxoplasma gondii isolates and toxoplasmosis seroprevalence in stray cats of Izmir, Turkey. PlosOne, 9, e104930.

10. Dao A, Fortier B, Soete M ve ark. (2001): Successful reinfection of chronically infected mice by a different Toxoplasma gondii genotype. Int J Parasitol, 31, 63-65.

11. Döşkaya M, Caner A, Ajzenberg D ve ark. (2013): Isolation of Toxoplasma gondii strains similar to Africa 1 genotype in Turkey. Parasitol Int, 62, 471-474.

12. Dubey JP, (2010): Toxoplasmosis of Animals and Humans. Second edition, CRC Press, Boca Raton.

13. Dubey JP, Zhu XQ, Sundar N ve ark. (2007): Genetic and biological characterization of Toxoplasma gondii isolates of cats from China. Vet Parasitol, 145, 352-356.

14. Dubey JP, Velmurugan GV, Chockalingam A ve ark. (2008): Genetic diversity of Toxoplasma gondii isolate from chickens from Brazil. Vet Parasitol, 157, 299-305.

15. Dumetre A, Ajzenberg D, Rozette L ve ark. (2006): Toxoplasma gondii infection in sheep from Haute-Vienne, France: seroprevalence and isolate genotyping by microsatellite analysis. Vet Parasitol, 142, 376-379.

16. Grigg ME, Ganatra J, Boothroyd JC ve ark. (2001): Unusual abundance of atypical strains associated with human ocular toxoplasmosis. J Infect Dis, 184, 633-639.

17. Halos L, Thébault A, Aubert D ve ark. (2009): $A n$ innovative survey underlining the significant level of contamination by Toxoplasma gondii of ovine meat consumed in France. Int J Parasitol, 40, 193-200.

18. Herrmann DC, Pantchev N, Globokar Vrhovec M ve ark. (2010): Atypical Toxoplasma gondii genotypes identified in oocysts shed by cats in Germany. Int J Parasitol, 40, 285-292.

19. Howe DK, Sibley LD (1994): Toxoplasma gondii: analysis of different laboratory stocks of the $R H$ strain reveals genetic heterogeneity. Exp Parasitol, 78, 242-245.

20. Jungersen G, Jensen L, Rask MR ve ark. (2002): Nonlethal infection parameters in mice separate sheep Type II Toxoplasma gondii isolates by virulence. Comp Immunol Microbiol Infect Dis, 25, 187-195.

21. Karakavuk M, Aldemir D, Mercier A ve ark. (2018): Prevalence of toxoplasmosis and genetic characterization of Toxoplasma gondii strains isolated in wild birds of prey and their relation with previously isolated strains from Turkey. PLoS One, 18, e0196159.

22. Khan A, Jordan C, Muccioli C ve ark. (2006): Genetic divergence of Toxoplasma gondii strains associated with ocular toxoplasmosis, Brazil. Emerging Infect Dis, 12, 942949.

23. Lehmann T, Marcet PL, Graham DH ve ark. (2006): Globalization and the population structure of Toxoplasma gondii. Proc Nat Acad Sci USA, 103, 11423-11428.

24. Mahami-Oskouei M, Moradi M, Fallah E ve ark. (2017): Molecular detection and genotyping of Toxoplasma gondii in chicken, beef, and lamb meat consumed in Northwestern Iran. Iran J Parasitol, 12, 38-45.
25. Mor N, Arslan MO (2007): Seroprevalence of Toxoplasma gondii in sheep in Kars Province. Kafkas Univ Vet Fak Derg, 13, 165-170.

26. Owen MR, Trees AJ (1999): Genotyping of Toxoplasma gondii associated with abortion in sheep. J Parasitol, 85, 382-384.

27. Saeij JP, Boyle JP, Boothroyd JC (2005): Differences among the three major strains of Toxoplasma gondii and their specific interactions with the infected host. Trends Parasitol, 21, 476-481.

28. Saeij JP, Boyle JP, Coller S ve ark. (2006): Polymorphic secreted kinases are key virulence factors in toxoplasmosis. Science, 314, 1780-1783.

29. Satbige AS, Sreekumar C, Rajendran C ve ark. (2017): Isolation and characterization of Toxoplasma gondii from small ruminants (sheep and goats) in Chennai City, South India. J Parasit Dis, 41, 869-873.

30. Scwab EK, Zhu XQ, Majumdar D ve ark. (2014): Geographical patterns of Toxoplasma gondii genetic diversity revealed by multilocus PCR-RFLP genotyping. Parasitol, 141, 453-61.

31. Sevgili M, Babür C, Nalbantoğlu S ve ark. (2005): Determination of seropositivity for Toxoplasma gondii in sheep from Sanlurfa Province. Turk J Vet Anim Sci, 29, 107-111.

32. Sevinc F, Kamburgil K, Dik B ve ark. (2000): The seroprevalence of toxoplasmosis by indirect fluorescent antibody (IFA) test in ewes with and without abortion in Konya province. Firat Univ Saglık Bilim Derg, 14, 137-142.

33. Sibley LD, Boothroyd JC (1992): Virulent strains of Toxoplasma gondii comprise a single clonal lineage. Nature, 359, 82-85.

34. Silva LA, Andrade RO, Carneiro AC ve ark. (2014): Overlapping Toxoplasma gondii genotypes circulating in domestic animals and humans in southeastern Brazil. PLoS One, 9, e90237.

35. Su C, Howe DK, Dubey JP ve ark. (2002): Identification of quantitative trait loci controlling acute virulence in Toxoplasma gondii. Proc Natl Acad Sci USA, 99, 10753 10758.

36. Su C, Zhang X, Dubey JP (2006): Genotyping of Toxoplasma gondii by multilocus PCR-RFLP markers: A high resolution and simple method for identification of parasites. Int J Parasitol, 36, 841-848.

37. Su C, Schwab EK, Zhou P ve ark. (2010): Moving towards an integrated approach to molecular detection and identification of Toxoplasma gondii. Parasitol, 137, 1-11.

38. Velmurugan GV, Dubey JP, Su C (2008): Genotyping studies of Toxoplasma gondii isolates from Africa revealed that the archetypal clonal lineages predominate as in North America and Europe. Vet Parasitol, 155, 314-318.

39. Weiss LM, Kim K (2007): Toxoplasma gondii, The Model Apicomplexan: Perspectives and Methods. Academic Press, Amsterdam.

40. Yıldız K, Babür C, Kılıç S ve ark. (2000): Investigation of anti-Toxoplasma antibodies in slaughtered sheep and cattle as well as in workers in the abattoir of Kırıkkale. Turkiye Parazitol Derg, 24, 180-185.

41. Yildiz K, Kul O, Gokpinar S ve ark. (2014): The relationship between seropositivity and tissue cysts in sheep naturally infected with Toxoplasma gondii. Turk J Vet Anim Sci, 38, 169-175. 